\title{
Neck circumference in adolescents and cardiometabolic risk: A sistematic review
} \author{
Joel Alves Lamounier ${ }^{5}$

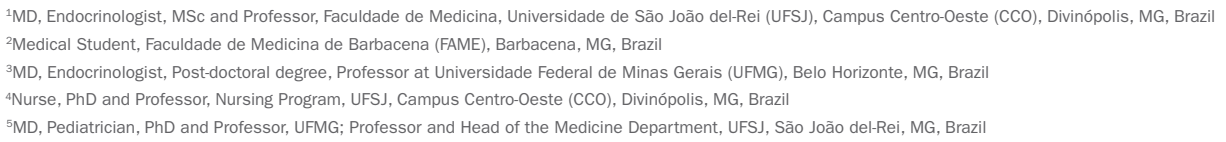

Aisha Aguiar Morais ${ }^{1 *}$, Urjel Aguiar Bouissou Morais², Maria Marta Sarquis Soares ${ }^{3}$, Márcia Christina Caetano Romano ${ }^{4}$,

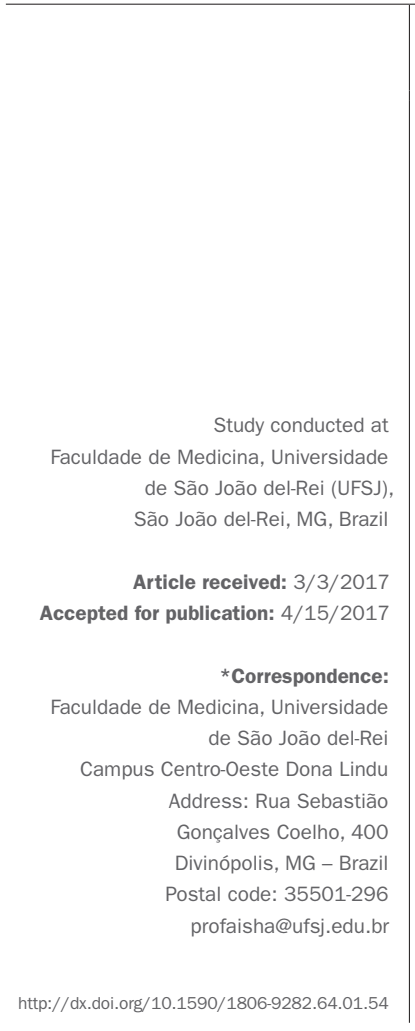

\section{SUMmARY}

Objective: To critically analyze articles on the relation between neck circumference (NC) in adolescents and: body mass index, fat distribution, metabolic syndrome and its individual components, and cardiovascular risk.

Method: Systematic review undertaken by two independent researchers using the Pubmed/Medline, Lilacs/Medline, Scielo and Cochrane databases in English, Spanish and Portuguese in the period comprising the past 5 years.

Results: Eighteen (18) articles were selected. The articles show an association between NC in adolescents and body fat (BMI), central fat distribution (WC), metabolic syndrome and several of its individual components, and cardiovascular risk. Some values are proposed for NC cutoff points as a diagnostic tool for nutritional status, high blood pressure and pre-hypertension, cardiovascular risk, insulin resistance and metabolic syndrome. We identified a percentile curve constructed for Brazilian adolescents.

Conclusion: There is a shortage of studies with representative samples, variety at the NC measurement sites, and the age of the participants, which makes it difficult to establish definitive landmarks.

Keywords: Neck. Adolescents. Metabolic Syndrome X. Obesity. Cardiovascular Diseases. Obesity. Waist Circumference. Anthropometry. Insulin Resistance. Hypertension. Triglycerides. Cholesterol. Blood Glucose. Review.

\section{INTRODUCTION}

Obesity among adolescents is becoming increasingly prevalent and worrying worldwide due to the increased risk of complications in adulthood or even earlier, during adolescence itself. ${ }^{1-3}$ Both the amount and the distribution of body fat are related to insulin resistance (IR), dyslipidemia, high blood glucose and cardiovascular diseases. ${ }^{4-6}$

Direct measurements of body fat (densitometry, electrical bioimpedance, computed tomography, magnetic resonance imaging) are costly and not readily available in clinical practice. Body mass index (BMI) and waist circumference (WC) are the most commonly used measurements in medical appointments because they are uncomplicated and accessible. The former indicates the amount of body fat and the latter, its location, without however distinguishing between visceral and subcutaneous fat types. ${ }^{7,8}$

WC measurement, in turn, may be affected by factors such as an increase in the postprandial period and variation with respiratory movements, or cause embarrassment due to exposure of the abdomen. In addition, this type of measurement does not yet rely on a standardized methodology or reference values defined for adolescents.

Neck circumference (NC) then appears as a more consistent alternative for assessing central fat distribution, originally, in adults ${ }^{8-11}$ and, more recently, in adolescents. ${ }^{12}$ NC correlates with cardiometabolic risk as much as visceral fat does. ${ }^{10}$

This measurement is socially accepted, has intra- and inter-examiner reproducibility, ${ }^{13}$ but should be avoided 
in patients with conditions that increase the volume of the cervical region such as in patients with goiter.

Our systematic review aimed at describing and critically analyzing articles on the relation between NC in adolescents and their BMI, fat distribution, metabolic syndrome (MetS) and its individual components, and cardiovascular risk (CVR).

\section{Method}

Our review aims at providing access to and a critical analysis of the most current information on the subject.

We designed it in accordance with the Prisma guidelines for systematic reviews: formulation of a problem, bibliographic review, selection of articles, analysis of data and presentation of the review. ${ }^{14}$ For this, two independent researchers did a search on January $20^{\text {th }}, 2016$. We used the following Health Science Descriptors (DeCS, Portuguese acronym for Descritores em Ciências da Saúde) to search the Lilacs/Medline and Scielo databases: neck, adolescent, obesity, waist circumference, anthropometry, cardiovascular diseases, metabolic syndrome, insulin resistance, high blood pressure, triglycerides, cholesterol, blood glucose. The terms we used for the search in the Cochrane database were neck and adolescent. In the case of Pubmed/Medline, we used the following Medical Subject Headings (MeSH): adolescent, obesity, body mass index, adiposity, anthropometry, cardiovascular diseases, metabolic syndrome, hypertension, insulin resistance, triglyceride, high blood glucose.

We selected the articles according to their title and abstract, using the eligibility criteria. The inclusion criteria were: study languages (English, Spanish, and Portuguese); and time filter: 5 years; target population: humans, adolescent as defined by the WHO criteria (10 to 19 years of age); outcome of interest: relation between NC (dependent variable) in adolescents and overweight/obesity, visceral fat/WC, MetS and its components, CVD (independent variables). The exclusion criteria were based on the type of study: editorial, case report, expert opinion.

Both researchers read the selected articles in full and analyzed them. Occasional divergence in selection was resolved by consensus. Upon reading the articles, we carried out a secondary search with the selection of articles from the bibliography contained in the primary documents of the previous search, respecting the inclusion criteria. Figure 1 summarizes the steps of article selection we used for our review.

\section{Results}

\section{Characterization of studies}

We systematized the main features of the selected articles in one table (Table 1).

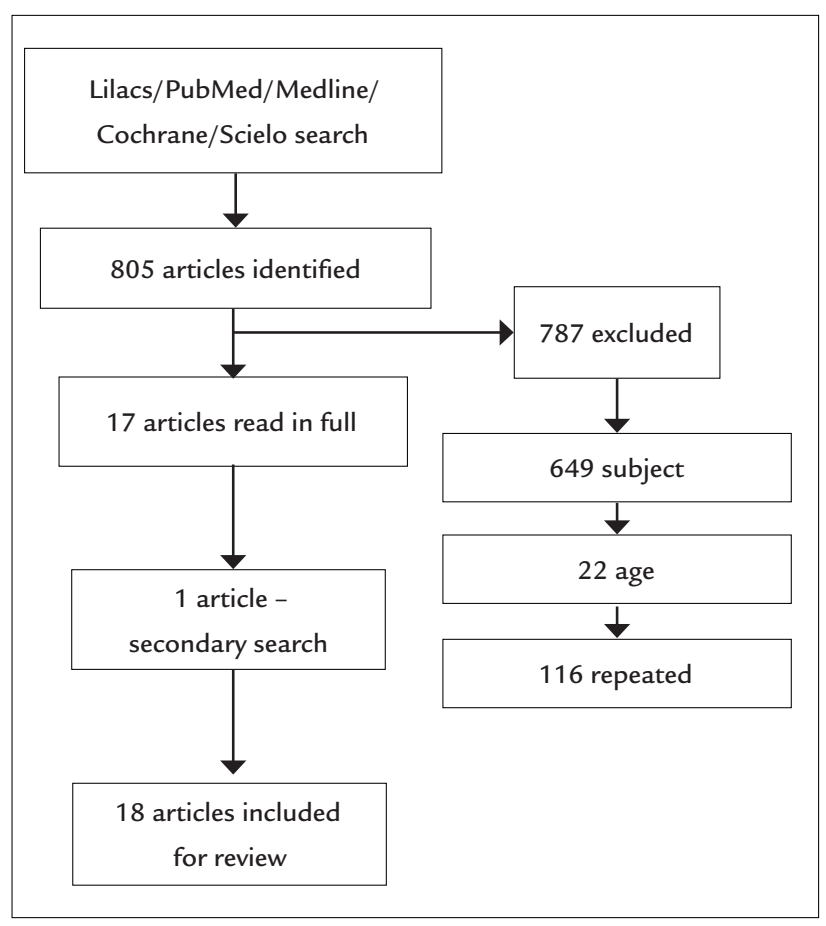

FIGURE 1 Article search flow.

We varied the samples from the selected studies (150 to 6,802 , median 1,507 subjects), five of which were random. One of the studies ${ }^{15}$ explained that a sample had been chosen out of convenience because of difficulty in adherence.

Most of the studies selected their patients from the same schools where they studied, ${ }^{15-23}$ with only four of them involving students coming from public schools, ${ }^{15,19,20,22}$ whereas other four used data from patients who were already being followed up in an outpatient clinic., ${ }^{8,2426}$

Two studies evaluated the same population of inpatients awaiting non-cardiac elective surgery ${ }^{27,28}$ and one study obtained a sample from the general population. ${ }^{29}$ Brazil was the country of origin of the largest number of publications selected (37.5\%), but China had the largest number of subjects studied.

\section{$\mathrm{NC}$ and the technical aspects to measuring it}

Seventy-two percent $(72 \%)$ of the studies performed measurements at the level of the thyroid cartilage, an easily identifiable reference landmark. The other measurement sites were: just below the thyroid cartilage, ${ }^{23}$ the cricoid cartilage $^{8,30}$ and at halfway the height of the neck..$^{21,26}$

In only three studies the measurements had been taken as duplicates or triplicates, ${ }^{15,23,25}$ a fact of little relevance due to the already well-documented reproducibility of this type of measurement. ${ }^{13}$ Eleven (11) studies ${ }^{8,16,17,19,20,22,23,27-29,31}$ mentioned the training of examiners. In one study ${ }^{17}$ repro- 


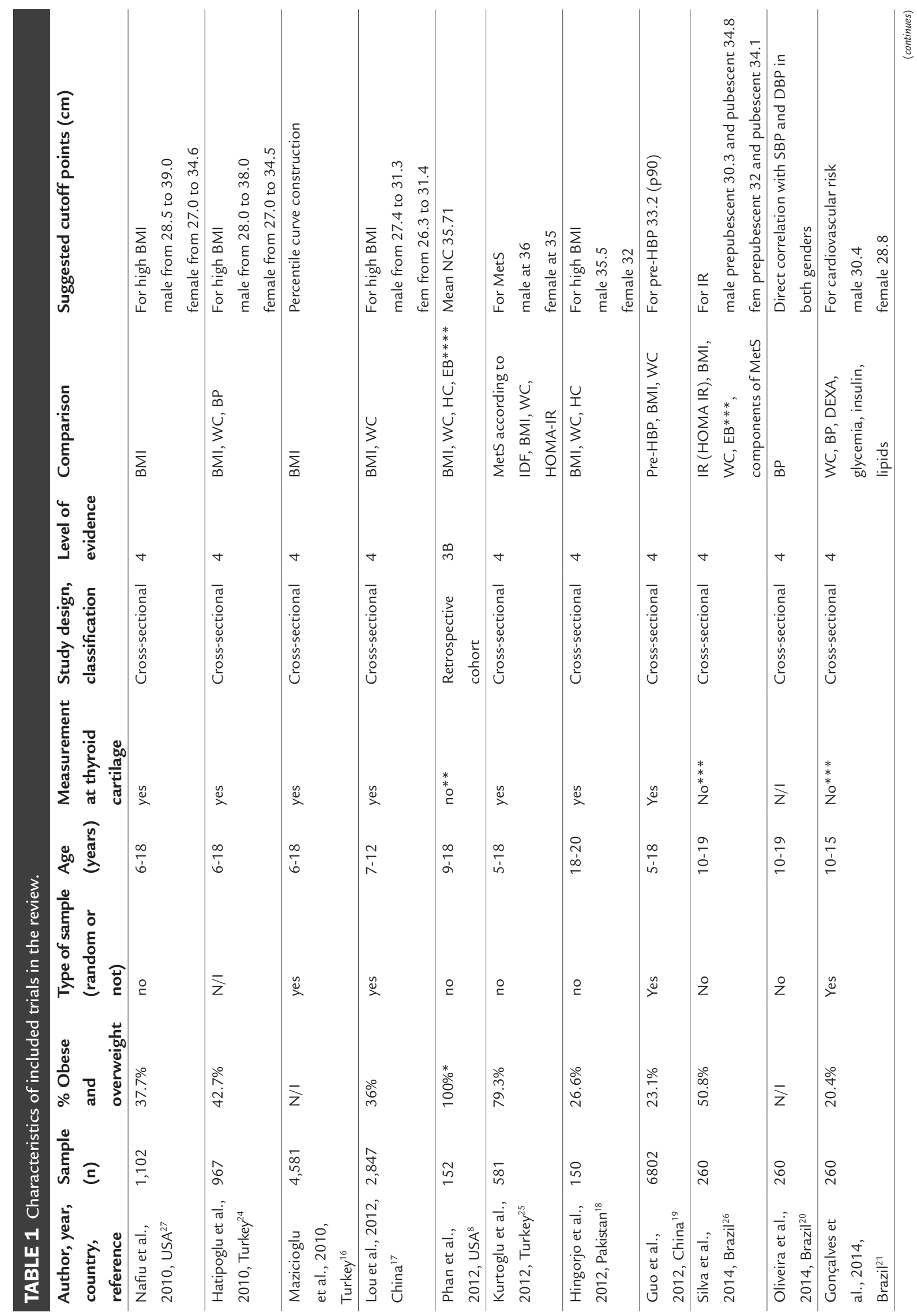




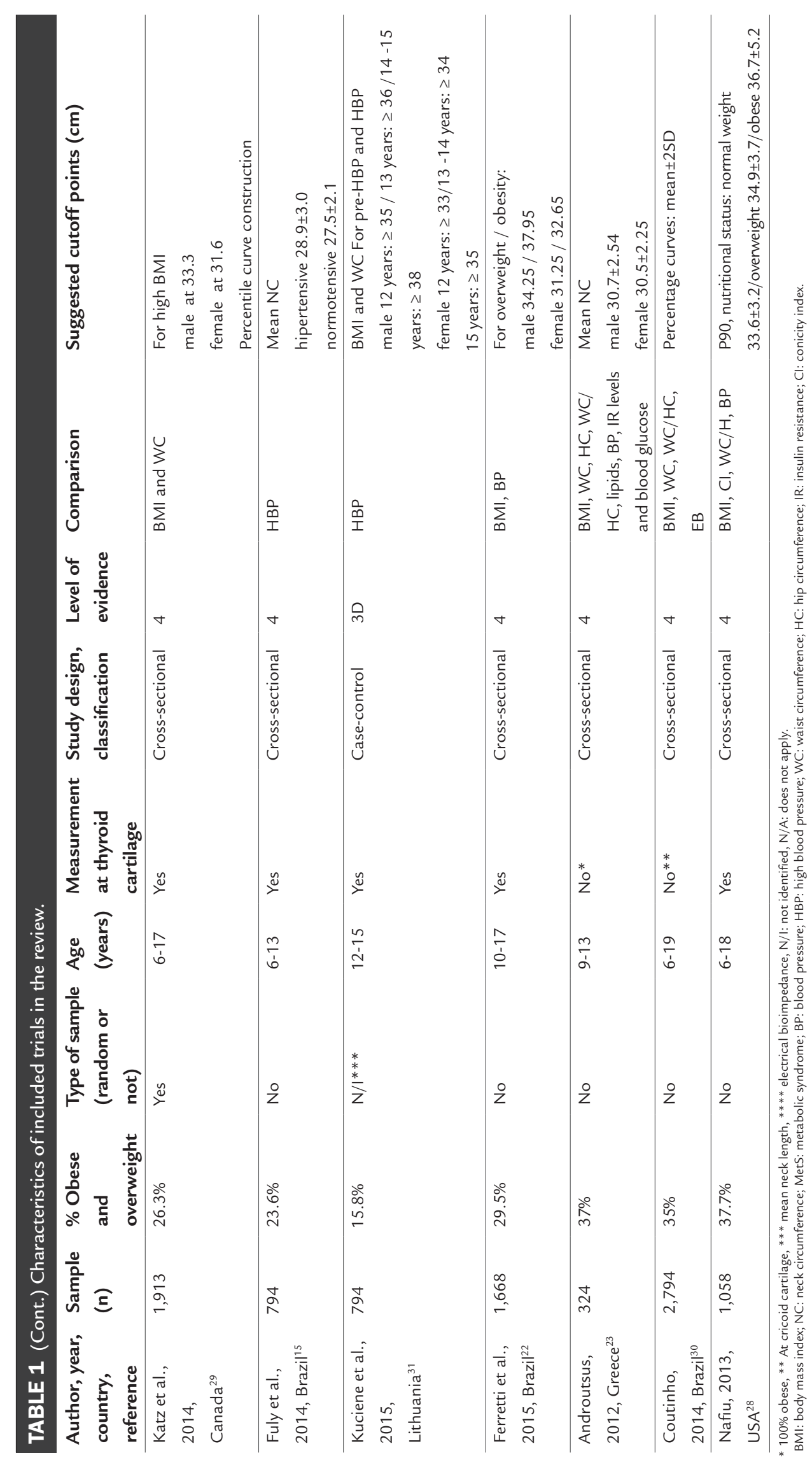


ducibility tests of its anthropometric measurements were run. Only six studies ${ }^{17,18,25-27,30}$ declared the exclusion of subjects bearer of cervical lesions that could falsify the measurements, such as masses or deformities. In the other articles, exclusion criteria were based on the use of medications ${ }^{26}$ or pathologies ${ }^{19,25,26,30}$ that could influence cardiometabolic parameters.

\section{NC: age, gender, pubertal stage and nutritional status}

Only two studies presented age groups in perfect agreement with our review objectives. ${ }^{20,26}$ The remaining studies also included children ${ }^{8,15-17,19,23-25,27-30}$ or young adults ${ }^{18}$ (Figure 2).

The studies showed homogeneous distribution of the participants between the genders. NCs tended to be larger in males and to increase with age in all studies suggesting cutoff points by gender and/or age. The difference in measurements increased from $11^{16,29,30}$ up to 18 years of age, at which age it was found to stabilize. By then, NCs were $4 \mathrm{~cm}$ larger in males than in females. ${ }^{16}$

Pubertal staging was performed in five studies, ${ }^{22-26}$ two of which were self-assessed. ${ }^{22,26}$ Three studies used these data to identify cutoff points along an ROC curve, ${ }^{22,24,26}$ one calculated the mean according to the pubertal stage ${ }^{22}$ and yet another study adjusted the data by the degree of pubertal development. ${ }^{24}$

Considering the participants' nutritional status is an extremely important aspect when evaluating $\mathrm{NC}$ re- sults. Obese or overweight participants accounted for $20-40 \%$ of the sample in $69 \%$ of the studies reporting such data (Figure 3).

\section{$\mathrm{NC}$ as predictor of cardiometabolic risk factors}

The most investigated relation of $\mathrm{NC}$ was that with BMI, and it was statistically significant in all articles that evaluated it. ${ }^{16-19,21,22,24-31}$ Although this finding was consensual, the way it was assessed was not. As previously mentioned, the NC measurement site varied, as did the landmark used for BMI assessment (CDC, ${ }^{26-29} \mathrm{WHO}^{18,21-23,30}$, Group of Chinese Obesity Task Force 2004, ${ }^{17}$ International Obesity Task Force, ${ }^{16,19,31}$ unspecified ${ }^{8,15,24,25}$ ).

The second most investigated relation, whose finding was universal, was that between WC and NC. ${ }^{17-21,24-31}$ The most frequent measurement site was the midpoint between the last rib and the iliac crest. ${ }^{15,17,18,20,21,25-27,30,31}$ There were also measurements taken at the top of the iliac crest $^{24,29}$ at the navel level, ${ }^{19}$ whereas another two studies did not explicitly state the measurement $\operatorname{site}^{28}$ of choice.

Other manners of evaluating body fat were used. A positive association was found between $\mathrm{NC}$ and cutaneous folds, ${ }^{22}$ electrical bioimpedance, ${ }^{8,26,30}$ densitometry, ${ }^{21}$ body adiposity index (BAI) (the ratio of WC [waist circumference] $[\mathrm{cm}]$ to height $[\mathrm{m}]$ multiplied by the square root of the height). ${ }^{31}$

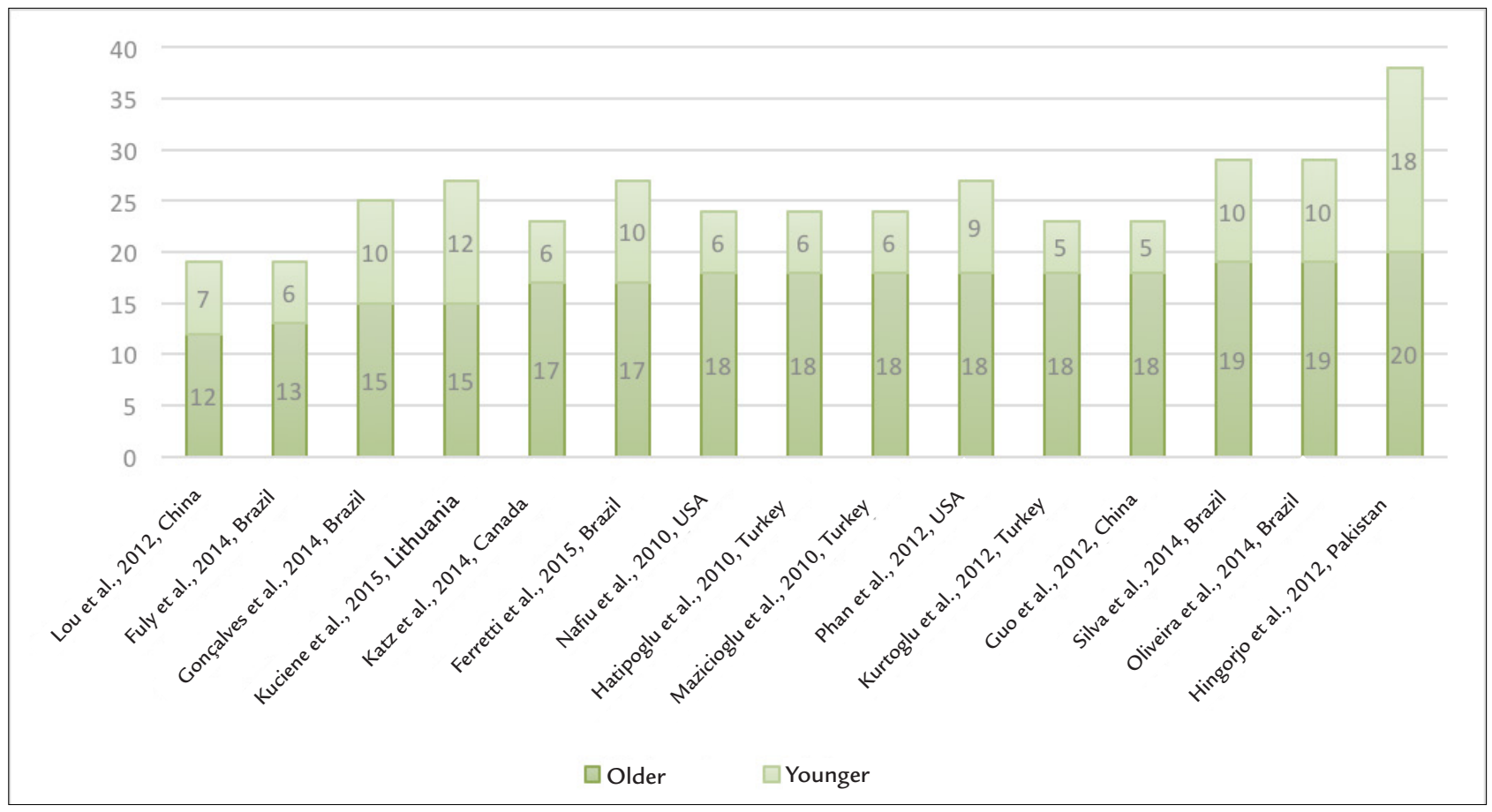

FIGURE 2

Age groups by study. 


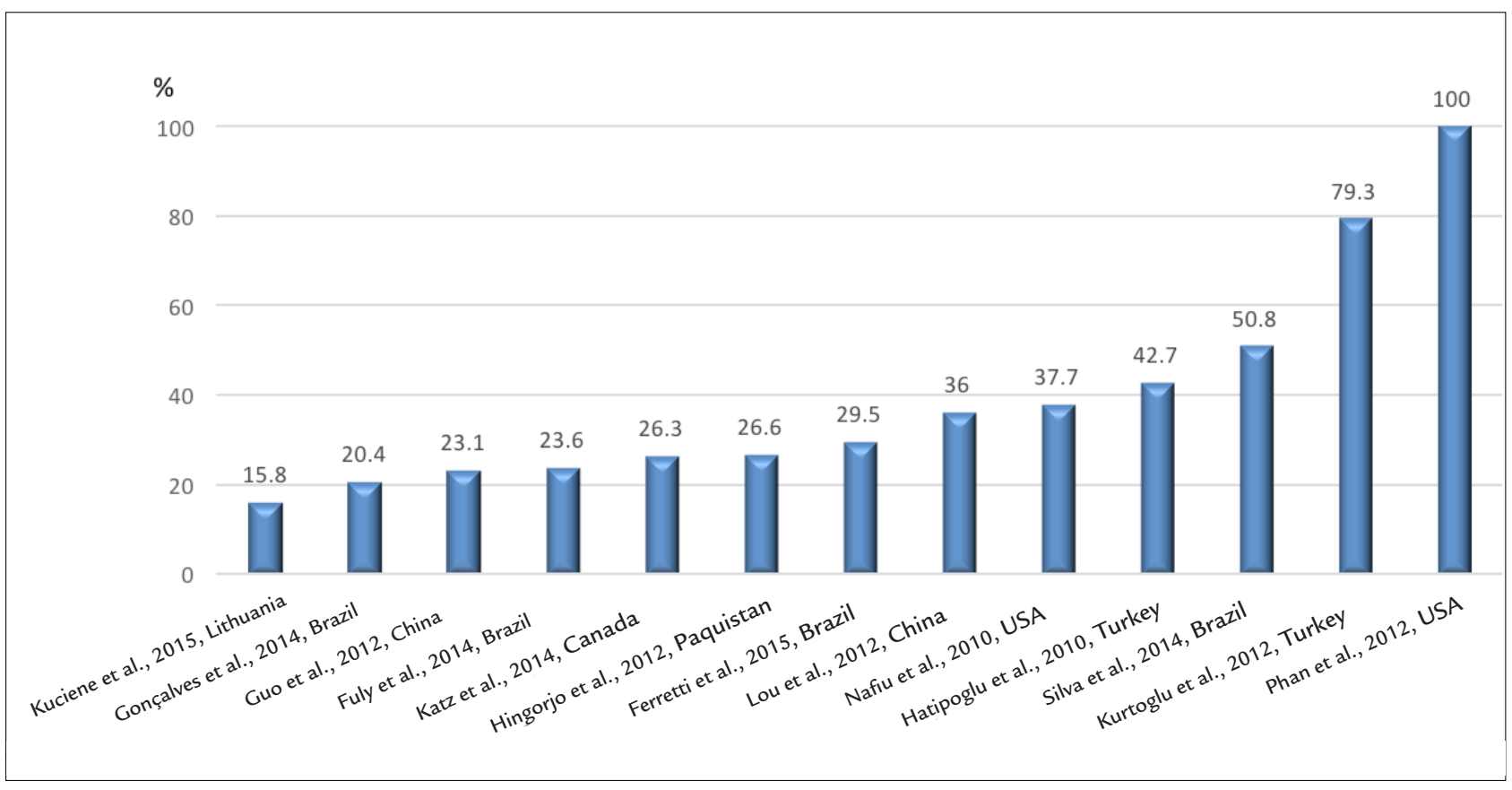

FIGURE 3

Percentage of obese and overweight.

Some studies assessed the relation between NC and IR or several parameters used to diagnose MetS. There was a correlation between NC and IR (HOMA-IR), ${ }^{21,25,26}$ fasting insulinemia, ${ }^{21,25,26}$ but not blood glucose. ${ }^{25,26}$

With regard to cardiometabolic parameters, a correlation was found with systolic blood pressure (SBP), diastolic blood pressure (DBP) $)^{21,23,25,26}$ and triglycerides; ${ }^{21,23,25,26,28}$ and a negative correlation was found with HDL cholesterol. ${ }^{21,23,25,26}$ The correlation with total cholesterol was less consistent, being either positive $e^{8}$ or negative ${ }^{21}$ depending on the study.

\section{NC in Brazil}

Our review includes 6,036 Brazilian participants, distributed across six cross-sectional studies. Only one used random sampling ${ }^{21}$ and also suggested cutoff points for NC.

The suggested cutoff points are specific for each metabolic parameter evaluated (body fat, triglycerides, HDL cholesterol, blood pressure, fasting blood glucose, fasting insulinemia).

One of the studies ${ }^{30}$ suggested NC percentile curves after assessing 2,794 adolescents. Normality was defined as the values included within \pm 2 standard deviations of the mean, by gender and age. However, sampling was not random, overweight was more frequent in its population than the national average. Furthermore, pubertal staging was not performed and $\mathrm{NC}$ measurements were taken at the cricoid cartilage level. The authors' justification was that the increase in thyroid cartilage size is not unanimous in pubescent boys.

Two studies ${ }^{22,26}$ generated specific cutoff points for pubertal staging. In one of them, ${ }^{26}$ in which most participants were overweight, the measurement was performed at halfway the height of the neck, with the goal of predicting IR. In yet another group, ${ }^{22}$ in which about one-third of the participants were overweight, the measurement was made at the level of the laryngeal prominence and the objective was to predict nutritional status. The findings were close to those obtained by a similar Turkish study. ${ }^{24}$

\section{Discussion}

In 1956, when evaluating the neck fold, Vague et al. were pioneers in suggesting that fat distribution in the upper body had clinical implications. ${ }^{32}$ Experimental studies corroborated this suggestion by demonstrating increased lipolysis in the presence of fat preferentially stored in the upper body. ${ }^{5,33}$ Lipolysis progresses with a release of free fatty acids in excess, insulin resistance in the muscles, an increase in the endogenous production of glucose and VLDL cholesterol by the liver. ${ }^{34}$ Clinically, these changes manifest as the components of metabolic syndrome. This state is evident in the presence of excess visceral and adipose tissue, as is the case with neck circumference measurements. $5,6,35,36$ 
Determining NC reference values for screening overweight and CVR factors in adolescents has some particularities. In addition to the effects of growth per se, pubertal development causes changes in body fat distribution and is associated with a projection of the thyroid cartilage at its midline in males. Thus, setting specific cutoff points by gender and age may be insufficient.

Only one Brazilian study made NC measurement at the thyroid cartilage level (the most frequent site in the selected international literature): it generated cutoff points by gender, nutritional status and pubertal stage ${ }^{22}$ (data not shown). This stratification appears to be more important among eutrophic adolescents, whose cardiometabolic risk would not be identified in a BMI assessment.

In both adults and adolescents, the articles selected for our review were unanimous in attesting the correlation between $\mathrm{NC}$ and the two measurements most frequently used in clinical practice to estimate adiposity, namely BMI and WC. The correlation still held true, despite the lack of unanimity regarding the anatomical parameters for measuring NC, WC and the reference values for classifying BMI, WC and NC. However, the studies in adolescents are more heterogeneous.

Like the studies in adults, they do consider the difference in NC values between genders, which grows more relevant from puberty on. In addition, since they also usually include the pediatric age group, they present a panorama of growth from the point of view of NC.

As expected, as the age group approaches 18 years, the studies in adolescents suggest that the values for monitoring overweight status get closer to those proposed for adults: 33 to $35 \mathrm{~cm}$ for females and 37 to $38.5 \mathrm{~cm}$ for males. ${ }^{9,37-40}$ This can be better appreciated when comparing the NC percentile scores in Turks between 6 and 18 years of age ${ }^{16}$ and in a representative sample of the adult population from the same country. ${ }^{40}$

Cardiovascular diseases are the leading cause of death in adults. Studies in adults have explored NC's ability to predict the risk thereof either directly or by means of their risk factors. ${ }^{10,37-44}$

As seen in adolescents, $\mathrm{NC}$ values could be correlated with SBP and DBP, ${ }^{10,37,39,42,45}$ triglycerides, ${ }^{39,41,42,45} \mathrm{IR},{ }^{10,37}$ but also blood glucose, , $^{10,37,39,41,42,45}$ total cholesterol, ${ }^{39,41,45}$ HDL $^{10,37,39,42}$ and LDL. ${ }^{39,41,45}$

The proposed values are identical to those indicated for overweight screening: 33 to $35 \mathrm{~cm}$ for females and 37 to $39 \mathrm{~cm}$ for males. ${ }^{37-39}$

Even after adjustment for adiposity as measured by $\mathrm{BMI}$ or WC, NC remained a good predictor for diabetes, ${ }^{42}$ insulin resistance ${ }^{10}$ and metabolic syndrome, ${ }^{40}$ but not for coronary atherosclerotic load. ${ }^{46}$
Obesity in childhood increases morbidity and mortality in adulthood, a fact corroborated by a study with 23.9 years of follow-up. ${ }^{47}$ As a matter of fact, there has already been a downward trend in the increase in life expectancy over the last 30 years. ${ }^{48}$ Additionally, even before adulthood, obesity can lead to cardiometabolic complications, ${ }^{49}$ and NC could serve as an instrument for screening.

Our review presents a compilation of the most current articles on the association of NC to nutritional status and cardiometabolic risk factors in adolescents. While searching through the articles, we located a systematic review from 2014 that included the subject of NC in children. ${ }^{12}$ We had already selected all three articles cited in this systematic review in our bibliographic review.

The topic is current and relevant and encourages the introduction of NC measurements in both the clinical practice and epidemiological studies. Nevertheless, there are still some gaps to be filled by new studies. To date, there is still no measurement site defined for taking NC measurements, which thus hampers comparisons between studies. Most studies disregard the effects of pubertal development on NC. Furthermore, there are few studies with random samples. There may also be variations according to ethnicity, similar to WC, which also call for a larger number of studies. On the other hand, our review already shows several proposed landmarks for the screening of overweight/obesity status and cardiovascular risk factors, separated by gender and age group. We also selected articles suggesting percentile curves. In summary, our review, in agreement with articles already published on adults, lists studies demonstrating the association between NC and body fat (BMI), central fat distribution (WC), metabolic syndrome and several of its individual components, and CVR in the adolescent population.

The simple and rapid measurement may be useful for a secondary prophylaxis, serving as the basis for the continuation of propedeutics in adolescents. This is an extremely desirable measure, given its simplicity, low cost and reproducibility, which should inspire further studies that can propose more definitive cutoff points.

\section{Conclusion}

The studies we found and our systematic review demonstrate the recent interest in NC in adolescents in several countries for assessing body fat and CVR factors. Inexpensive, simple and reproducible, not only is it able to predict general and localized body adiposity, but also the complications thereof. However, there is a shortage of studies with representative samples, which makes it difficult to establish cutoff values by gender and age group. Routine clinical use 
still depends on the standardization of NC measurement and its interpretation. Furthermore, almost all of the studies included in our investigation used a cross-sectional methodology, which limits the determination of cause and effect due to their undefined temporality.

\section{ACKNOWLEDGMENTS}

The authors would like to thank Cristina Maria Bouissou Morais Soares for her invaluable suggestions and for generously reviewing our manuscript.

\section{INDIVIDUAL CONTRIBUTIONS}

Aisha Aguiar Morais and Urjel Bouissou Aguiar Morais carried out the investigation, selection and critical reading of the articles and wrote the integrative review. Joel Alves Lamounier and Márcia Christina Caetano Romano critically reviewed the intellectual content of the manuscript and approved its final version.

\section{Conflict of interest}

The authors declare no conflict of interest.

\section{Resumo}

Circunferência do pescoço de adolescentes e risco cardiometabólico: uma revisão sistemática

Objetivo: Analisar criticamente artigos referentes à relação entre a circunferência do pescoço (CP) de adolescentes e: índice de massa corporal, distribuição de gordura, síndrome metabólica e seus componentes individuais e risco cardiovascular.

Método: Revisão sistemática realizada por dois pesquisadores independentes nas bases de dados Pubmed/Medline, Lilacs/Medline, Scielo e Cochrane nos idiomas inglês, espanhol e português nos últimos 5 anos.

Resultados: Foram selecionados 18 artigos. Os artigos demonstram a associação entre CP de adolescentes e gordura corporal (IMC), distribuição central gordura (CC), síndrome metabólica e vários de seus componentes individuais, e risco cardiovascular. Existem propostas de pontos de corte da CP para o diagnóstico do estado nutricional, hipertensão e pré-hipertensão, risco cardiovascular, resistência insulínica e síndrome metabólica. Foi identificada ainda uma curva de percentis construída para adolescentes brasileiros.

Conclusão: Há escassez de estudos com amostras representativas, variedade nos locais de medição da CP e na idade dos participantes, o que dificulta estabelecimento de referências definitivas.
Palavras-chave: Pescoço. Adolescente. Síndrome X Metabólica. Doenças Cardiovasculares. Obesidade. Circunferência da Cintura. Antropometria. Resistência à Insulina. Hipertensão. Triglicérides. Colesterol. Glicemia. Revisão.

\section{REFEREnCES}

1. Organización Panamericana de la Salud. La salud en las Américas; edición de 2002. Vol I. Publicación Científica y Técnica 582. Washington: Organización Panamericana de la Salud; 2002.

2. Swinburn BA, Sacks G, Hall KD, McPherson K, Finegood DT, Moodie ML, et al. The global obesity pandemic: shaped by global drivers and local environments. Lancet. 2011; 378(9793):804-14.

3. Instituto Brasileiro de Geografia e Estatística. Ministério do Planejamento, Orçamento e Gestão. Pesquisa de Orçamentos Familiares 2008/2009 Despesas, rendimentos e condições de vida. Rio de Janeiro: IBGE; 2010 [cited 2016 Jul 3]. Available from: http://www.ibge.gov.br/home/estatistica/ populacao/condicaodevida/pof/2008_2009/POFpublicacao.pdf.

4. Daniels SR, Morrison JA, Sprecher DL, Khoury P, Kimball TR. Association of body fat distribution and cardiovascular risk factors in children and adolescents. Circulation. 1999; 99(4):541-5.

5. Sjöström CD, Håkangård AC, Lissner L, Sjöström L. Body compartment and subcutaneous adipose tissue distribution: risk factor patterns in obese subjects. Obes Res. 1995; 3(1):9-22.

6. Fox CS, Massaro JM, Hoffmann U, Pou KM, Maurovich-Horvat P, Liu CY, et al. Abdominal visceral and subcutaneous adipose tissue compartments: association with metabolic risk factors in the Framingham Heart Study. Circulation. 2007; 116(1):39-48.

7. Cornier MA, Després JP, Davis N, Grossniklaus DA, Klein S, Lamarche B, et al.; American Heart Association Obesity Committee of the Council on Nutrition; Physical Activity and Metabolism; Council on Arteriosclerosis; Thrombosis and Vascular Biology; Council on Cardiovascular Disease in the Young; Council on Cardiovascular Radiology and Intervention; Council on Cardiovascular Nursing, Council on Epidemiology and Prevention; Council on the Kidney in Cardiovascular Disease, and Stroke Council. Assessing adiposity: a scientific statement from the American Heart Association. Circulation. 2011; 124(18):1996-2019.

8. Phan TL, Maresca MM, Hossain J, Datto GA. Does body mass index accurately reflect body fat? A comparison of anthropometric measures in the longitudinal assessment of fat mass. Clin Pediatr (Phila). 2012; 51(7):671-7.

9. Ben-Noun L, Sohar E, Laor A. Neck circumference as a simple screening measure for identifying overweight and obese patients. Obes Res. 2001; 9(8):470-7.

10. Preis SR, Massaro JM, Hoffmann U, D’Agostino RB Sr, Levy D, Robins SJ, et al. Neck circumference as a novel measure of cardiometabolic risk: the Framingham Heart study. J Clin Endocrinol Metab. 2010; 95(8):3701-10.

11. Vallianou NG, Evangelopoulos AA, Bountziouka V, Vogiatzakis ED, Bonou MS, Barbetseas J, et al. Neck circumference is correlated with triglycerides and inversely related with HDL cholesterol beyond BMI and waist circumference. Diabetes Metab Res Rev. 2013; 29(1):90-7.

12. Magalhães EI, Sant'Ana LF, Priore SE, Franceschini SC. Waist circumference, waist/height ratio, and neck circumference as parameters of central obesity assessment in children. Rev Paul Pediatr. 2014; 32(3):273-81.

13. LaBerge RC, Vaccani JP, Gow RM, Gaboury I, Hoey L, Katz LS. Inter- and intra-rater reliability of neck circumference measurements in children. Pediatr Pulmonol. 2009; 44(1):64-9.

14. Prisma-Statement - Transparent reporting of systematic reviews and metaanalysis [cited $2016 \mathrm{Jul} 3$ 3]. Available from: http://www.prisma-statement.org/

15. Fuly JT, Giovaninni NP, Marcato DG, Alves ER, Sampaio JD, Moraes LI, et al. Evidence of underdiagnosis and markers of high blood pressure risk in children aged 6 to 13 years. J Pediatr (Rio J). 2014; 90(1):65-70.

16. Mazicioglu MM, Kurtoglu S, Ozturk A, Hatipoglu N, Cicek B, Ustunbas HB. Percentiles and mean values for neck circumference in Turkish children aged 6-18 years. Acta Paediatr. 2010; 99(12):1847-53.

17. Lou DH, Yin FZ, Wang R, Ma CM, Liu XL, Lu Q. Neck circumference is an accurate and simple index for evaluating overweight and obesity in Han children. Ann Hum Biol. 2012; 39(2):161-5

18. Hingorjo MR, Qureshi MA, Mehdi A. Neck circumference as a useful marker of obesity: a comparison with body mass index and waist circumference. J Pak Med Assoc. 2012; 62(1):36-40. 
19. Guo X, Li Y, Sun G, Yang Y, Zheng L, Zhang X, et al. Prehypertension in children and adolescents: association with body weight and neck circumference. Intern Med. 2012; 51(1):23-7.

20. Oliveira AV, Costa ACPJ, Pascoal LM, Santos LH, Chaves ES, Araújo MFM. Correlação entre indicadores antropométricos e pressão arterial de adolescentes. Texto Contexto Enferm. 2014; 23(4):995-1003.

21. Gonçalves VSS, Faria ER, Franceschini SCC, Priore SE. Neck circumference as predictor of excess body fat and cardiovascular risk factors in adolescents. Rev Nutr. 2014; 27(2):161-71.

22. Ferretti RL, Cintra IP, Passos MA, Moraes Ferrari GL, Fisberg M. Elevated neck circumference and associated factors in adolescents. BMC Public Health. 2015; $15: 208$.

23. Androutsos O, Grammatikaki E, Moschonis G, Roma-Giannikou E, Chrousos GP, Manios Y, et al. Neck circumference: a useful screening tool of cardiovascular risk in children. Pediatr Obes. 2012; 7(3):187-95.

24. Hatipoglu N, Mazicioglu MM, Kurtoglu S, Kendirci M. Neck circumference: an additional tool of screening overweight and obesity in childhood. Eur J Pediatr. 2010; 169(6):733-9.

25. Kurtoglu S, Hatipoglu N, Mazicioglu MM, Kondolot M. Neck circumference as a novel parameter to determine metabolic risk factors in obese children. Eur J Clin Invest. 2012; 42(6):623-30

26. Silva CC, Zambon MP, Vasques ACJ, Rodrigues AMB, Camilo DF, Antonio MARGM, et al. Circunferência do pescoço como um novo indicador antropométrico para predição de resistência à insulina e componentes da síndrome metabólica em adolescentes: Brazilian Metabolic Syndrome Study. Rev Paul Pediatr. 2014; 32(2):221-9.

27. Nafiu OO, Burke C, Lee J, Voepel-Lewis T, Malviya S, Tremper KK. Neck circumference as a screening measure for identifying children with high body mass index. Pediatrics. 2010; 126(2):e306-10.

28. Nafiu OO, Zepeda A, Curcio C, Prasad Y. Association of neck circumference and obesity status with elevated blood pressure in children. J Hum Hypertens. 2014; 28(4):263-8

29. Katz SL, Vaccani JP, Clarke J, Hoey L, Colley RC, Barrowman NJ. Creation of a reference dataset of neck sizes in children: standardizing a potential new tool for prediction of obesity-associated diseases? BMC Pediatr. 2014; 14:159.

30. Coutinho CA, Longui CA, Monte O, Conde W, Kochi C. Measurement of neck circumference and its correlation with body composition in a sample of students in São Paulo, Brazil. Horm Res Paediatr. 2014; 82(3):179-86.

31. Kuciene R, Dulskiene V, Medzioniene J. Association of neck circumference and high blood pressure in children and adolescents: a case-control study. BMC Pediatr. 2015; 15:127.

32. Vague J. The degree of masculine differentiation of obesities: a factor determining predisposition to diabetes, atherosclerosis, gout, and uric calculous disease. Am J Clin Nutr. 1956; 4(1):20-34.

33. Jensen MD. Lipolysis: contribution from regional fat. Annu Rev Nutr. 1997; 17:127-39.

34. Nielsen S, Guo Z, Johnson CM, Hensrud DD, Jensen MD. Splanchnic lipolysis in human obesity. J Clin Invest. 2004; 113(11):1582-8.
35. Yang L, Samarasinghe YP, Kane P, Amiel SA, Aylwin SJ. Visceral adiposity is closely correlated with neck circumference and represents a significant indicator of insulin resistance in WHO grade III obesity. Clin Endocrinol (Oxf). 2010; 73(2):197-200.

36. Wohl D, Scherzer R, Heymsfield S, Simberkoff M, Sidney S, Bacchetti P, et al. The associations of regional adipose tissue with lipid and lipoprotein levels in HIV-infected men. J Acquir Immune Defic Syndr. 2008; 48(1):44-52.

37. Wang X, Zhang N, Yu C, Ji Z. Evaluation of neck circumference as a predictor of central obesity and insulin resistance in Chinese adults. Int J Clin Exp Med. 2015; 8(10):19107-13.

38. Yang GR, Yuan SY, Fu HJ, Wan G, Zhu LX, Bu XL, et al.; Beijing Community Diabetes Study Group. Neck circumference positively related with central obesity, overweight and metabolic syndrome in Chinese subjects with type 2 diabetes: Beijing Community Diabetes Study 4. Diabetes Care. 2010; 33(11):2465-7.

39. Zhou JY, Ge H, Zhu MF, Wang LJ, Chen L, Tan YZ, et al. Neck circumference as an independent predictive contributor to cardio-metabolic syndrome. Cardiovasc Diabetol. 2013; 12:76

40. Onat A, Hergenç G, Yüksel H, Can G, Ayhan E, Kaya Z, et al. Neck circumference as a measure of central obesity: associations with metabolic syndrome and obstructive sleep apnea syndrome beyond waist circumference. Clin Nutr. 2009; 28(1):46-51.

41. Ben-Noun LL, Laor A. Relationship between changes in neck circumference and cardiovascular risk factors. Exp Clin Cardiol. 2006; 11(1):14-20.

42. Preis SR, Pencina MJ, D’Agostino RB Sr, Meigs JB, Vasan RS, Fox CS. Neck circumference and the development of cardiovascular disease risk factors in the Framingham Heart Study. Diabetes Care. 2013; 36(1):e3.

43. Dantas EM, Pinto CJ, Freitas RP, Medeiros ACQd. Agreement in cardiovascular risk rating based on anthropometric parameters. Einstein. 2015; 13(3):376-80

44. Medeiros CA, Bruin VM, Castro-Silva C, Araújo SM, Chaves Junior CM, Bruin PF. Neck circumference, a bedside clinical feature related to mortality of acute ischemic stroke. Rev Assoc Med Bras. 2011; 57(5):559-64.

45. Ben-Noun L, Laor A. Relationship of neck circumference to cardiovascular risk factors. Obes Res. 2003; 11(2):226-31.

46. Chagas P, Caramori P, Barcellos C, Galdino TP, Gomes I, Schwanke CHA. Associação de diferentes medidas e índices antropométricos com a carga aterosclerótica coronariana. Arq Bras Cardiol. 2011; 97(5):397-401.

47. Franks PW, Hanson RL, Knowler WC, Sievers ML, Bennett PH, Looker HC. Childhood obesity, other cardiovascular risk factors, and premature death. N Engl J Med. 2010; 362(6):485-93.

48. Olshansky SJ, Passaro DJ, Hershow RC, Layden J, Carnes BA, Brody J, et al. A potential decline in life expectancy in the United States in the 21st century. N Engl J Med. 2005; 352(11):1138-45.

49. Weiss R, Caprio S. The metabolic consequences of childhood obesity. Best Pract Res Clin Endocrinol Metab. 2005; 19(3):405-19. 